\title{
The electoral consequences of the financial and economic crisis in Europe
}

\author{
Enrique Hernández and Hanspeter Kriesi \\ European University Institute \\ Florence
}

To be published in EJPR 2016

\begin{abstract}
We analyse the electoral consequences of the Great Recession by combining insights from economic voting theories, and the literature on party system change. Taking our cues from these two theoretical perspectives, we assess the impact of the Great Recession on the stability and change of Western, Central and Eastern European party systems. We start from the premise that, to fully assess the impact of the contemporary crisis, classic economic voting hypotheses focused on incumbent parties need to be combined with accounts of long-term party system change provided by realignment and dealignment theories. The empirical analysis draws on an original dataset of election results and economic and political indicators in 30 European democracies. The results indicate that during the Great Recession economic strain was associated with sizable losses for incumbent parties and an increasing destabilization of Western European party systems, while its impact was significantly weaker in Central and Eastern European countries, where political rather than economic failure appeared to be more relevant. In line with the realignment perspective, the results also reveal that in Western Europe radical populist right, radical left, and non-mainstream parties benefited the most form the economic hardship, while the support for mainstream parties decreased further.
\end{abstract}




\section{INTRODUCTION}

In this paper, we analyse the electoral consequences of the Great Recession in Europe from two theoretical perspectives: economic voting and party system change. The vast literature on economic voting suggests that voters react to this kind of crisis by punishing the incumbents and by voting in favour of the opposition. Economic voting occurs in 'normal' times, and we may expect it to occur to an even greater extent under the impact of the contemporary economic crisis. The worldview of this perspective is essentially a short-term and cyclical one: voters follow the business cycle and reward or punish incumbents according to the economic situation. The alternative perspective is that of the development and change of party systems. Contrary to the economic voting literature, the equally vast literature on this perspective takes a long-term view on voting patterns and expects them to move as a result of long-term shifts in the structure of social conflicts. As old social conflicts lose in importance and new conflicts emerge from the fundamental transformation of society, the pattern of political conflict is changing as well. As new political actors emerge and old political actors adapt to the changing conflict structure, the pattern of voting gets destabilized, giving rise to processes of dealignment/realignment in the party system. Applying these two perspectives to the analysis of the electoral consequences of the Great Recession allows us to provide a comprehensive assessment of the voters' reactions to this deep economic crisis and its impact on European party systems.

We argue that the joint consideration of these two theoretical perspectives provides new insights into the political consequences of the Great Recession in Europe. While in normal times economic voting theories may provide an adequate account of the impact of the economy on electoral politics, in extraordinary times, the long-term perspective of party system change needs to be incorporated into the analysis. Applied to a critical moment like the Great Recession, the economic voting perspective only tells a partial story about the impact of the economy on voting. 
In contexts like the Great Recession, punishment of the incumbents by the voters is not only likely to occur in much greater proportions, but its consequences are also likely to be longerlasting than the shifts of the voters to the mainstream opposition parties. In contrast to normal times, during the crisis, the predicted extraordinary punishment of incumbents' parties is expected to contribute to the destabilization of European party systems (i.e. increase their volatility) and, as a consequence, to accelerate pre-existing processes of party system change. Hence, in terms of the perspective of party systems' theory, the Great Recession may constitute a 'critical juncture', which is not only likely to erode the support of incumbent parties, but of all the mainstream parties. By giving rise to extraordinary punishments of all the mainstream parties, the economic crisis may accelerate pre-existing de-/realignment processes.

The economic voting perspective constitutes the starting point for our analysis of the consequences of the Great Recession. Building on this perspective and combining it with the perspective of party system change allows us to formulate more detailed expectations about the specific type of parties that are likely to lose and gain support during the Great Recession. Incorporating the predictions of economic voting theory into the broader and more general expectations that can be derived from party systems change theories will provide us with a more complete account of the electoral consequences of the Great Recession.

Our empirical analyses draw on a database of electoral outcomes at the aggregate level, complemented with political and economic indicators, for 27 EU-member states, plus Iceland, Norway and Switzerland ${ }^{1}$. Our dataset includes data on electoral returns for all relevant parties in these countries in the two elections preceding the outbreak of the economic crisis and of all the elections that have taken place since then up to summer 2014. We start out by presenting some

\footnotetext{
${ }^{1}$ Given its late accession to the EU Croatia is excluded.
} 
considerations of the two theoretical perspectives with respect to the electoral consequences of the Great Recession. Next, we present our data. Then, we move on to the presentation of the results and we conclude by a summary discussion.

\section{THEORY}

The literature on economic voting provides us with a baseline model for how the crisis has played out in electoral terms. This literature is based on the assumption of instrumentally rational voters, who reward the incumbents with their vote, when the economy is good, and punish them when the economy is bad. According to this literature, it is not the personal financial situation, which is decisive for the economic vote, but the perception of the national economy (Duch and Stevenson 2008, Lewis-Beck and Stegmaier 2007). Empirical studies on economic voting document that it is both pervasive and variable, depending on the context. According to Duch and Stevenson's (2008: 65) overall estimates the median economic vote magnitude is about 5 percent. By comparison, Powell and Whitten (1993: 410) estimated the typical cost of governing at the aggregate level at just 2 per cent. These results were obtained by analysing a large number of 'normal' elections. There is now also a growing literature on economic voting in the Great Recession, which shows that the electoral punishment of the incumbents has been massive and that it is a function of the depth of the recession (Bartels 2014, Kriesi 2014). In line with this literature, we expect that, in a period of economic turmoil, economic considerations are likely to be more salient for the decision of rewarding or punishing the incumbent. During this period, citizens should be more likely to judge the incumbent as a function of the decline in economic performance than in normal times. 
The economic voting literature suggests that the size of the electoral punishment for economic performance is conditioned by the political context. More specifically, it suggests that it is less the objective economic conditions than the perception of government responsibility for the economic conditions that is of crucial importance for economic voting. Thus, Powell and Whitten's (1993) documented that the clarity of political responsibility conditions economic voting: the voters' assessment of the government's economic performance only plays a role, if the institutional context allows them to clearly attribute the responsibility for the economic performance to the government. In addition, perceived constraints of the government's manoeuvring space also influence the extent to which incumbents are punished. Hellwig and Samuels (2007) show that voters in more open economies are less likely to evaluate incumbents on the basis of fluctuations in economic growth. In the context of the Great Recession, the attribution of responsibility to the EU has led to lower levels of national economic voting in Southern Europe (Lobo and Lewis-Beck 2012). Similarly, Clarke and Whitten (2013) attributed the limited impact of economic voting in the 2009 German elections to 'countervailing factors' a lack of clarity of responsibility in the German polity and the availability of alternative actors to be blamed.

Given that perceptions are crucial for the punishment of incumbents, we would like to point out three implications which seem to us of major importance in the context of the Great Recession. First, we follow Marsh and Mikhaylov (2012), who argue that it is not so much the size of the economic decline that is decisive for the electoral punishment, but the dramatic manner in which the crisis developed. In accounting for the extraordinary severity of Fianna Fáil’s losses in the 2011 Irish elections, Marsh and Mikhaylov attribute key importance to two events that have focused the minds of the Irish voters - the bank guarantee in Fall 2008, and the 
Irish withdrawal from the bond market in Fall 2010. In a similar vein, Beissinger and Sasse (2014) point to IMF-interventions as critical conditions for austerity protests in Central- and Eastern Europe. In the Irish case, the second moment preceded the ECB/IMF intervention by a few days, but we would still argue that such an intervention was already looming large and, in any case, it may serve as an indicator for critical moments in the unfolding of the Great Recession in the countries particularly hard hit by the economic crisis.

Second, we would like to point out that the severity of the economic crisis is likely to be perceived differently as a function of past experience with economic crises. Building on relative deprivation theory (Gurr 1970), we expect the relative decline in performance to be decisive for the electoral consequences - relative in temporal terms within one country as well as in terms of cross-national comparisons. Relative deprivation theory is based on the idea that citizens' grievances and behaviours are a function of the perceived discrepancy between their expectations about the conditions of life to which they believe to be entitled to, and the realization of these expectations. People's expectations with respect to the economy, in turn, are likely to be influenced by the past economic performance of their own country - their country’s past performance in absolute terms and in terms relative to other, comparable countries. Without any reference to this theory, Coffey (2013) has recently introduced the closely related notion of 'pain tolerance' to explain the economic voting of Czech citizens. She showed that the punishment of incumbents is a function of the departure of economic indicators from the long-term average, i.e. relative to the country's past economic performance. In other words, poor past performance increases the voters' tolerance with respect to poor current performance and vice versa for good past performance. In line with this finding, we expect the citizens of Central- and East European (CEE) countries in general to have greater tolerance with respect to poor economic performance 
than citizens of West European (WE) countries. When the Great Recession hit the populations of the CEE countries already had a lot of experience with economic hardship as a result of the difficulties encountered in the course of their transition to market economies. For example, the Baltic countries that were hit by massive unemployment increases already had a lot of experience with high levels of unemployment. By contrast, WE citizens, especially in Greece, Spain or Ireland, had experienced economic growth accompanied by a sharp decline in unemployment rates in the decades prior to the crisis, a trend which they probably expected to continue, and which made the equally sharp increases of unemployment during the crisis particularly galling for them.

Third, and in a similar vein, we expect the impact of economic decline on the incumbent vote to be less severe in the first post-crisis election than in subsequent post-crisis elections. In the immediate aftermath of the Lehman Brothers' collapse, most European countries suffered an economic setback, which means that, in cross-national comparative terms, all incumbents performed badly. As time progressed, however, the economic prospects of most, but not all of the European countries improved. The voters of the countries where the economy continued to stagnate or even experienced a pronounced double-dip recession, among other things as a result of the austerity measures that really started to have an impact on the respective economies, are likely to have perceived the incumbents' failure as particularly serious - not only compared to the other countries, but also compared to the past, pre-crisis record.

This discussion can be summarized in four hypotheses: the punishment of the incumbents in the Great Recession should be greater ...

H1: ....in hard hit countries ('severity of the crisis’ hypothesis) 
H2: ...in countries which experienced comparatively little economic hardship in the recent past (i.e. WE countries) ('past experience' hypothesis)

H3: ... in countries with dramatic unfolding of key events (involving ECB/IMF intervention) ('dramatic events’ hypothesis)

H4: ... and, especially, in second post-crisis elections ('timing' hypothesis)

In the economic voting literature, the political context conditions are typically thought to have a short-term impact on the voting choice. This literature does not take into account longterm trends in the development of party systems. This is a serious shortcoming when it comes to the analysis of a major economic crisis. In contrast to 'normal times', when the focus on cyclical effects and incumbent governments seems justified, the intervention of a major crisis may accentuate long-term trends of party system change, and it may even lead to a substantial modification of the structure and equilibrium of the party system in a given country.

As is well known from the literature on the political consequences of economic crises in Latin America (Morgan 2012, Seawright 2012, Roberts 2013), such crises may lead to party brand dilution, to a decline of partisanship and, eventually, to a process of dealignment in the party system. Hence, while the economic voting perspective provides a baseline for the analysis of the effects of the crisis, it needs to be complemented with an approach that allows us to take into account its potential effects on the party system as a whole and the pre-existing long-term trends of party system change. As we indicated above, during the Great Recession the punishment of incumbents as a consequence of the declining economic performance is likely to be substantial. This provides the first condition for the destabilization and change of party 
systems as a result of the economic crisis. In normal times voters are likely to turn to mainstream opposition parties, but under extraordinary circumstances voters may lose confidence in all the parties that have habitually governed. This is expected to occur especially if the crisis drags on and successive governments of different mainstream composition prove to be incapable of improving the economic situation. Under such conditions, voters may be more likely to move beyond mainstream opposition parties altogether and opt for parties not so closely associated with the current economic and political system. The cumulated punishment of mainstream parties may accelerate and/or reshape pre-existing de-/realignment processes in the party system, and as a consequence produce further increases in party system volatility.

From such a long-term perspective, it is important to note that the observers of West European party systems have identified profound long-term trends that, at the time of the onset of the Great Recession, have been going on for several decades. Essentially, there are three interpretations of these trends in the literature: the realignment, the dealignment, and the cartel party detachment perspectives (Kitschelt and Rehm 2015). The third perspective, which is a radical version of the second one, proposes that parties in Western Europe are losing their structural roots in society, their coherence and their representative function (Mair, 2013). Indicators of this long-term trend are declining voter turnout, declining party identification, decreasing party membership as well as increasing electoral volatility. Dealignment scholars have long pointed to the mainstream parties' declining embeddedness in social divisions of religion and class, and the increasing importance of issue-voting (see Franklin et al. 1992). This line of argument suggests that the increasing economic voting in times of a deep economic crisis is nothing but an intensification of a longer term trend of destabilization of European party systems. 
The realignment perspective does not contradict the dealignment scholars with regard to the overall destabilizing trends. However, it adds countervailing trends which eventually lead to a stable reconfiguration of the party systems: in the long run, strategic parties realign with changing preference distributions among voters, which are related to social structural transformations (Kitschelt/Rehm 2015, Häusermann/Kriesi 2015, Kriesi et al. 2006). Voters gravitate to parties with programmatic appeals congruent with their preferences. More specifically, a new cleavage opposes the low-skilled, nationalistic 'losers of globalization', who are mainly mobilized by parties of the populist radical right, to the high-skilled, cosmopolitan winners of globalization, who are mainly mobilized by Green, liberal and centre-left parties. In other words, this perspective adds more specific expectations about the party families that might be gaining ground in the Great Recession, which complement the main expectation of the economic voting perspective with regards to the lower support of incumbent parties. Since it is above all the 'globalization losers' who have been affected by the economic downturn, we can expect the parties that mobilize these groups of the population to benefit from the punishment of the incumbents, especially in the countries hardest hit by the crisis. Among the parties mobilizing such losers we find above all parties of the populist radical right, parties of the radical left (which have always mobilized the disadvantaged in class terms), and new parties more generally.

From the party systems perspective, CEE countries differ profoundly from those in WE, with far-reaching implications for the potential impact of the Great Recession. While the mainstream parties of WE party systems no longer seem to have the means to adequately represent their traditional constituencies, the CEE party systems have not yet produced mainstream parties that adequately represent them. When measured against different criteria of institutionalization CEE party systems appear to still be less institutionalized (Casal Bértoa 
2014). The most important empirical evidence for the lack of institutionalization of these party systems comes from Neff Powell and Tucker (2013), who show that the very high level of volatility in these systems since the democratic transition has above all been due to the entry and exit of parties.

The high volatility of CEE party systems is linked to the widespread dissatisfaction of the CEE publics with their political elites which predates the intervention of the economic crisis. The low level of political and administrative performance and the corresponding high level of corruption in these countries have contributed to the constitution of anti-elitist sentiments, which provided a general breeding ground for populist challengers, even before the economic crisis intervened (Pop-Eleches 2010: 232). In times of economic crisis, however, the tolerance for corruption that tends to have benefited from the previously good economic performances in these countries is likely to have diminished considerably (see Klasnja and Tucker 2013). In other words, in CEE countries, the Great Recession can be expected to have given rise to a combination of a political and an economic crisis. As a result of this particular combination of circumstances, the mobilization by new challengers in the party system has taken on particular characteristics in CEE. Ucen (2007: 54) has referred to the rise of a new ,centrist populism', and Deegan-Krause (2007: 152) called them a purely anti-elite populism 'focusing entirely on the need for 'new faces in government' as part of a major fight against corruption'. The tough antiestablishment appeal of these new populist challengers has been directed against all previous configurations of the ruling elite.

This discussion of the long-term trends in the party systems can be summarized in the following three hypotheses: 
H5: The Great Recession increasingly destabilizes the party systems in WE, whereas it has much less of a destabilizing effect on the party system in CEE ('destabilization’ hypothesis)

H6: The changing levels of corruption are contributing to the punishment of the incumbents and to the destabilization of the party systems in CEE, but not in WE ('corruption’ hypothesis)

H7: New parties, parties of the populist radical right and the radical left, as well as other non-mainstream parties, benefit from the crisis by receiving greater support in those WE countries most affected by the crisis ('deep crisis’ hypothesis)

\section{DATA AND OPERATIONALIZATION}

Our empirical analyses rely on a database of electoral outcomes, which includes data on electoral returns for all relevant parties in 30 European countries in the two national legislative elections preceding the outbreak of the Great Recession and of all national legislative elections that have taken place since then, up to and including the Slovenian elections in July 2014. We define as post-crisis elections all the national elections that took place after November 2008. Overall we cover 107 elections: 61 pre-crisis (two per country ${ }^{2}$ ) and 46 post-crisis, 30 of which are the first post-crisis election that took place in a given country, and 16 correspond to the second post-crisis election.

\footnotetext{
${ }^{2}$ Austria had an election in September 2008. We consider this election as pre-crisis, and we include 3 pre-crisis elections for Austria.
} 
To test our hypotheses we rely on four dependent variables ${ }^{3}$. First we analyse the role of the economic conditions by assessing their impact on the change in the vote share for the prime minister's party between a given election at time $t$ and $t+1$. Second, we analyse the electoral returns for the prime minister party at time $\mathrm{t}+1$ as a function of the votes it received in the previous election at time t. To characterize the overall effect of the crisis on the stability and change of party systems as a whole we rely, third, on electoral volatility measures, and, fourth, on the change in the support for individual parties between a given election at time $t$ and $t+1$. For the analysis of electoral volatility, we adopt the distinction between type-A volatility (volatility caused by the entry and exit of parties from the political system) and type-B volatility (volatility generated by vote switching between existing parties) (Neff Powell and Tucker 2013)

To measure the change in economic conditions in a given country, we rely on three economic indicators: change in GDP, change in the unemployment rate and change in government debt between the election at time $t$ and $t+1$. Given the expectation that citizens should be more likely to respond to general economic trends and not to the evolution of specific macroeconomic indicators we have combined these three indicators to create a summary measure of a country’s economic misery. An exploratory factor analysis on these three items yields a onefactor solution, with all items loading strongly on one single dimension. ${ }^{4}$. Based on the factor scores we estimate our misery indicator, which takes higher values for worsening economic conditions. To measure the relative decline in performance across countries we compute an additional variable (“cross-country relative misery”) that indicates the degree to which the change in misery in a given country deviates from the pre or post-crisis average change in misery in WE and CEE countries respectively. To compute this variable the misery indicator of each

\footnotetext{
${ }^{3}$ See appendix B for details about variables' operationalization

${ }^{4}$ See Table A1 in appendix A.
} 
country-election observation is divided by the average misery of its corresponding geographical location (WE or CEE) in the corresponding time period (pre-crisis or post-crisis). Hence, higher values indicate a relatively higher increase in misery. In order to test our third hypothesis we rely on a variable that captures whether a given country was part of an IMF program that implied policy conditionality.

To characterize the political context, we compute a variable that reflects the change in corruption between the election at time $\mathrm{t}$ and $\mathrm{t}+1$ based on the Corruption Perception Index, with higher values indicating an increase in corruption. We also introduce a dummy variable distinguishing between single-party governments and coalition governments to control for ‘clarity of responsibility'. In order to control for the permissiveness of the electoral system, in the volatility models we control for the average district magnitude of each country. Following, Powell and Whitten (1993) we also introduce a variable that accounts for the short-term fluctuations in the government party's gains and losses in the previous elections (swing). Given the special character of Switzerland's 'prime minister' we also include a Switzerland dummy.

To test the hypotheses related to gains and losses of different types of parties in WE we classify parties in five mutually exclusive categories: new, radical left, populist radical right, non-mainstream, and mainstream parties. ${ }^{5}$ Parties that participate for the first time in a given election are included in the 'new' group irrespective of their ideology. In later elections they are included in their respective category. The radical left and populist radical right are defined based on their ideology. The rest of the parties are classified as either mainstream or non-mainstream. The mainstream parties encompass those parties that have played a key role in a country's party

\footnotetext{
${ }^{5}$ Only parties with parliamentary representation and receiving at least three percent of the vote share are included in the dataset.
} 
system since the post-war period, and cannot be classified among radical left or populist radical right parties. All the remaining parties are classified as non-mainstream. In total our sample includes 480 party-election observations: 203 mainstream, 165 non-mainstream, 52 radical left, 40 populist radical right, and 20 new parties ${ }^{6}$.

\section{RESULTS}

Following the economic voting model we start our analyses by assessing the effects of the economic context on the performance of the prime minister's party ${ }^{7}$. Given their different patterns of party competition and economic trends, in all the empirical analyses we distinguish between WE and CEE. Table 1 presents the results with respect to economic voting. The baseline Model 1 assesses the effect of changes in misery on the performance of the prime minister's party between two elections. As predicted by the economic voting approach, an increase in misery is associated with a worsening performance of the incumbent party at the next election. This effect is stronger in WE countries.

$<$ Table 1>

Model 2 tests whether, during the Great Recession, the punishment of the incumbents has been greater in hard hit countries ('severity of the crisis' hypothesis) and whether the punishment has become greater as the crisis progressed ('timing' hypothesis). In the case of WE both hypotheses are confirmed. During the economic crisis incumbent parties have been more

\footnotetext{
${ }^{6}$ Each election in which a party is present is treated as an independent observation of that party. Our WE sample includes a total of 135 parties. See appendix C.

${ }^{7}$ We replicated the analyses that rely on the vote share of the prime minister's party specifying as the dependent variable the vote share of all parties that form the cabinet. Our conclusions are not altered by this change in the specification of the dependent variable (results available upon request).
} 
severely punished as the economic conditions of their countries worsened while they were in office. Moreover, citizens seem to have perceived worsening economic conditions as a greater failure of the incumbent party as the crisis progressed, since a one unit increase in misery is associated with a greater punishment of the incumbent party in the second post-crisis election. Governments elected after the outbreak of the Great Recession which failed to redress the economic situation of their countries were more severely punished than governments that happened to be in office in hard hit countries when the Great Recession began. By contrast, in CEE there are no statistically significant differences between the pre and post-crisis periods, and some of the coefficients suggest that misery may even have had a more limited impact on the performance of incumbent parties during the post-crisis period. To further assess the differences between CEE and WE we pool our data and specify a three-way interaction between the misery indicator, the timing of the election, and the region ${ }^{8}$. Figure 1 summarizes these results and confirms that during the crisis there is a closer relationship between economic performance and incumbents' support in WE. Although none of the coefficients is statistically significant, the three-way interaction coefficients are correctly signed, indicating a lower importance of the economic conditions during the crisis in CEE.

\section{$<$ Figure $1>$}

To probe further into the importance of the relative decline in economic performance, we introduce in our models a variable capturing the relative decline in performance across countries (cross-country relative misery). Model 3 reveals that increasing cross-national relative misery significantly reduced the vote share of incumbents in WE, but not in CEE. At the same time, model 4 confirms that the negative effect of the relative decline in performance was significantly

\footnotetext{
${ }^{8}$ See model 1 in table A2 in appendix A.
} 
stronger during the Great Recession, and this negative effect strengthened further as the crisis progressed. These results confirm again the differences between WE and CEE, since all the relevant coefficients are substantially smaller for CEE countries. The differences between WE and CEE also show up in the explanatory power of all of our economic models. Models for WE explain around 40 percent of the variance in the dependent variable. By contrast, in CEE the models only account for a maximum of 20 percent of the variance. In sum, these results clearly confirm the 'severity of the crisis' and 'timing' hypotheses for WE, and they also support our fourth hypothesis about the differences between WE and CEE due to their past experience with economic crises.

Moving to the specific analysis of the impact of IMF interventions, model 5 assesses whether incumbents have lost support if their countries were part of an IMF program that implied policy conditionality. Results are clear, when compared to incumbents from other WE countries, and independently of the economic performance of their country, incumbents from countries where the IMF intervened could expect to lose as much as 10.8 percent of their support. Hence, in WE governments were heavily punished if they had to resort to the IMF to redress the economic situation of their countries. By contrast, in CEE the incumbents' loss of votes associated with an IMF intervention amounts to only 5.5 percent of their vote share.

In order to provide a comprehensive assessment of the electoral consequences of the Great Recession, we turn to the analysis of the stability and change of European party systems. The extraordinary punishment of incumbents during the Great Recession, predicted by the economic voting approach and confirmed by our empirical analyses, provides the first condition for the destabilization of the party systems of the countries most affected by the economic crisis. As outlined in the theory section, we expect this extraordinary punishment to be the catalyst of 
the acceleration of the long-term trends identified by the re/dealignment perspectives. In order to bridge the approaches of economic voting and party system change we first analyse the effect of the economic crisis on the stability and predictability of the support for the main actors in economic voting theories: the incumbents. We assess how the vote for the incumbents at time $t$ predicts the incumbents' vote share at time $t+1$, in the pre and post-crisis period. If this relationship becomes weaker in the post-crisis period, we have a first indication that party systems are becoming less stable during the crisis. Table 2 presents the results for this first test.

$<$ Table 2>

Three important results are conveyed by model 1 . First, for pre-crisis elections, the results confirm the expected key difference between WE and CEE party systems: in pre-crisis elections the previous vote share is a better predictor of the subsequent vote share in WE than in CEE ('percent vote time t' coefficient). This result indicates that sizable fluctuations in the electoral support of incumbent parties were uncommon in WE before the crisis. Second, during the Great Recession WE, but not CEE party systems became less stable in terms of the predictability of incumbent support. Figure 2 graphs this changing relationship. In WE, the close relationship between the incumbent's vote share at times $t$ and $t+1$ became weaker as the crisis progressed. The contrary seems to be the case in CEE countries. As the economic crisis advanced in CEE, the predictability of incumbent's vote share increased, although in this region the differences are not statistically significant. These results provide a first indication that the crisis may have affected the party systems of WE and CEE in different ways. ${ }^{9}$ Third, model 1 also includes a

\footnotetext{
${ }^{9}$ To test whether the differences between the two groups of countries are significant we pool our data and specify a three-way interaction of the incumbent's vote at time t, the timing of the election, and the region. The results confirm that the economic crisis has weakened the relationship between the previous and subsequent share of votes in WE, and it has strengthened this relationship in CEE countries. See table A.3 in appendix A.
} 
variable measuring change in corruption levels. The results reveal that while change in corruption levels is a relevant predictor of incumbent performance in CEE, this is not the case in WE. ${ }^{10}$ In line with the 'corruption hypothesis', corruption is only associated with a substantial reduction in the vote share of incumbent parties in CEE countries.

\section{$<$ Figure 2>}

We probe further into the overall effect of the crisis on the stability of the party systems by analysing the volatility of the elections covered. This is the most adequate indicator of the effects of the crisis on party systems, since it takes into account the electoral outcome of all parties. Table 3 presents a comparison of electoral volatility in the pre and post-crisis periods ${ }^{11}$. Although the total level of volatility is higher in CEE for both time periods, total volatility has increased substantially in WE during the Great Recession, while this has not been the case in CEE, even if the levels of misery have increased to a similar extent in both regions. In fact, typeB volatility, which refers to vote switching between existing parties, has only increased in WE. Moreover, in the course of the crisis, type-A volatility, which measures volatility caused by the entry and exit of new parties, has generally increased in both parts of Europe, but it increased more substantially in WE. In WE the relative increase in type-A volatility is higher than the relative increase in type-B volatility, which is a clear sign of the acceleration of the erosion of the party system in the West during the economic crisis. Comparing the levels of post-crisis total volatility to the ones calculated by Bartolini and Mair (1990) for the period 1885-1985, it appears that the majority of WE party systems are not undergoing 'normal' times. In the post-crisis

\footnotetext{
${ }^{10}$ The difference in the impact of corruption between WE and CEE is also confirmed by an interaction between the corruption and the region indicators in our pooled dataset. See model 1 table A.3 in appendix A.

${ }^{11}$ The 2012 Romanian elections are not included in the volatility analyses because they pose a problem for the coding of new parties.
} 
period, mean aggregate volatility (14.9) is almost twice as high as the one for the period 18851985 (8.2), and it is even higher than the volatility of turbulent times like the interwar period.

$<$ Table 3>

To analyse the role that fluctuations in the support of incumbent parties play for these changes in the levels of electoral volatility, Table 3 also provides the explained variance (R2) in the levels of total volatility by the changes in support of PM parties ${ }^{12}$. In the case of WE there are clear differences between the pre and post-crisis periods. While before the crisis changes in support of PM parties did not explain much of the variance in electoral volatility, in the postcrisis period they accounted for more than half of the corresponding variance. In CEE, where volatility levels were always higher, the differences in the variance explained between the pre and post-crisis periods are more limited. However, it is worth noting that in both periods change in support of the PM party appears to explain a substantial portion of the volatility variance. Hence, at least in the case of WE, these results support the idea that the central actors in the economic voting models (the incumbent parties) also play a crucial role for the stability and change of party systems during periods of deep economic crisis. Without the large changes in support of incumbent parties as a result of the worsening economic conditions it would have been unlikely that the party systems of WE countries would have reached these high levels of instability in a such a short period of time.

An analysis of the determinants of electoral volatility in WE and CEE provides a formal test of the 'destabilization’ and 'corruption’ hypotheses. Figure 3 summarizes the results of this analysis for both type-A and type-B volatility. It becomes apparent that in WE economic

\footnotetext{
${ }^{12}$ The model has been estimated using OLS with the total volatility measure as the dependent variable and the change in the share of votes for the PM as the independent variable.
} 
performance is an important determinant of both type-A and type-B volatility. As the economy worsens both types of volatility increase in WE. In CEE, however, levels of volatility appear to be unrelated to economic performance. In contrast, changes in the levels of corruption are associated with increases in type-B volatility in CEE but not in WE countries. The effect of corruption on type-A volatility is not statistically significant in any of the regions. As expected, economic performance increases volatility only in WE, and corruption is associated with higher volatility levels only in $\mathrm{CEE}^{13}$. Overall, these results provide further support for the 'destabilization' and 'corruption' hypotheses, and explain why volatility has increased in WE as a result of the Great Recession, while that has not been the case in CEE.

$<$ Figure 3 $>$

Having established that WE party systems became more unstable during the economic crisis and that the punishment of incumbent parties has been a relevant factor for this increasing instability, we now turn to an analysis of whether certain types of parties benefited from the party system instability brought about by the economic crisis. We restrict our analyses to WE because the crisis does not appear to have had a substantial impact on the stability of CEE party systems. To assess the gains and losses of the different types of parties we analyse the impact of the economic crisis on the change in the vote share from time $t$ to $t+1$ of the different types of parties. To assess whether the recession has accelerated pre-existing long-term trends of party system change, our main interest is to compare the performance of the different types of parties against the performance of mainstream parties. This is why we use mainstream parties as our reference category in the next models.

\footnotetext{
${ }^{13}$ To further assess these differences we pool our data and regress the summary measure of total volatility on the interactions of misery and region, and corruption and region. Model 3 Table A4 (appendix A) summarizes the results, which confirm that there are significant differences in the relationship between misery, corruption and volatility between WE and CEE countries.
} 
$<$ Table 4>

The results of model 1 in Table 4 confirm that, independently of the economic conditions, ruling is costly for incumbents. Parties that are part of government coalitions are expected to receive 3.6 percent less votes in the next election, and an extra 1.5 percent loss is added to the prime minister party. Model 2 examines the effects of economic conditions for different types of parties. The results reveal that in comparison to mainstream parties all the other party types generally make significant gains as the economy worsens. The populist radical right and new parties are the ones who benefit the most from the increases in misery. It is important to note that these and subsequent results hold under control for incumbent status, which suggests that mainstream opposition parties are not generally among the beneficiaries of the incumbents' losses. On the contrary, controlling for incumbency (prime minister and government status) increases in misery are associated with a lower vote share for mainstream parties (whether in government or in opposition), as indicated by the significant negative effect of the misery coefficient in model 2.

Moving now to the specific impact of the Great Recession, model 3 assesses whether the fact that a country required IMF assistance had consequences for the support of the different types of parties. The results reveal that IMF interventions implied an average loss of 4 percent of their votes for mainstream parties (direct effect of IMF-intervention), while all the other types of parties appear to have benefited from IMF interventions. Again, the parties that made the most significant gains were non-mainstream, radical right, and new parties. By definition new parties always increase their vote share. However, in countries with IMF interventions, the gains of new parties, with respect to mainstream parties, were twice as important as in countries that were not part of an IMF program. 
Finally, model 4 compares the effect of economic performance before and after the onset of the Great Recession. The purpose of this model is to test whether non-mainstream, peripheral (radical left and right) and new parties have always benefited from increases in misery, or whether this has only been the case during turbulent times. Figure 5 summarizes the results of this model. The differences between the two periods are unambiguous. Before the economic crisis, the economic situation had no apparent effect on the support of different types of parties, with the exception of radical right and new parties. The former received less, the latter more votes as the economy worsened, but none of the effects is statistically significant during the precrisis period. ${ }^{14}$ However, after the onset of the Great Recession the picture changed. First, mainstream parties started receiving fewer votes as the crisis became more severe, independently of their incumbent status. In fact, the average support for mainstream parties fell from 25 percent in the last pre-crisis election to 21 percent during the crisis period. Second, both non-mainstream and peripheral parties significantly benefited from the worsening economic conditions during the Great Recession. In this period, citizens of countries that suffered worsening economic conditions were more likely to defect from mainstream parties and to opt for either nonmainstream or peripheral parties. These results provide support for the 'deep crisis’ hypothesis, with regard to radical left and populist right parties as well as non-mainstream parties. It is in the countries most affected by the economic crisis, in terms of misery increase and IMF intervention, that we can find growing support for this kind of parties. Surprisingly, though, even if our aggregate data supports the idea that both the number and share of votes of new parties increased

\footnotetext{
${ }^{14}$ For the pre-crisis period none of the slopes in Figure 5 is statistically significant. For the post-crisis period the slopes of non-mainstream, radical left and radical right parties are positive and statistically significant at least at $\mathrm{p}<0.1$. For mainstream parties the slope is negative and statistically significant at $\mathrm{p}<0.01$. The effects are not statistically significant for new parties in any of the periods. Marginal effects for model 4 interactions are summarized in Table A5 appendix A.
} 
during the crisis (results not shown), model 5 suggests that during this period the gains of new parties were not more closely related to economic performance.

$<$ Figure 5 $>$

\section{Conclusion}

Our analyses by and large confirm the economic voting model, which we have used as a baseline for our analysis. In the Great Recession, incumbents have been heavily punished, especially in the hardest hit countries of WE. Electoral punishment of poor economic performance has generally been more limited in CEE, where populations have been more accustomed to economic hardship than in WE. If dramatic events like IMF interventions have increased punishment across Europe, their impact was especially severe in WE. Moreover, if the crisis dragged on, electoral punishment has been stepped up in WE, but not in CEE. Adopting a broader and more general perspective that shifts the focus from incumbent parties to the entire party system, we have been able to show, however, that, in WE, the cumulated effect of the Great Recession, goes far beyond the short-term punishment of incumbents. Thus, the predictability of the incumbents' vote share decreased substantially in the course of the Great Recession, while the overall volatility of the entire party system increased, but the other mainstream parties which habitually govern hardly benefited from the predicament of the incumbents. As expected by the party systems perspective, the main beneficiaries of the crisis and the increasing electoral volatility have been parties of the populist radical right and the radical left, as well as new parties. Radical parties benefited especially in the hardest hit countries, while the vote share of new parties has been rising independently of economic hardship in post-crisis elections across WE. Taken together, these results suggest that the long-term trend towards a destabilization of the WE party systems has been accelerated during the Great Recession. 
By contrast, the impact of the Great Recession on the party systems of CEE has been quite different. In these countries, incumbents have been punished less for economic hardship than for increasing corruption. Overall, the party systems of this region have followed an opposite trend to the one observed in WE. While the volatility of the CEE party systems is still higher than in WE, it is noteworthy that the volatility between established parties has actually decreased in the post-crisis period in CEE countries. Taking a long-term view, Lane and Ersson (1996: 130) suggested that, in terms of volatility, fractionalization, and polarization, the party systems of the two parts of Europe might have more in common than things that set them apart. While it is still premature to speak of convergence of the party systems in the two parts of Europe, the contrasting experience of WE and CEE party systems during the Great Recession suggests that the long-term trend may bring them closer together (see also Casal Bértoa 2014).

As we have pointed out in our theoretical discussion, all three interpretations of the longterm developments of WE party systems agree on the destabilizing trends. Where the realignment perspective differs from the other two is that it does not only identify destabilizing factors, but also points to countervailing trends that are expected to eventually lead to party system restructuration. The fact that the parties of the radical left and right as well as other nonmainstream parties (a category that includes above all Green parties) have been benefiting the most from the economic hardship suggests that the Great Recession has (so far) served as a catalyst for the acceleration of long-term trends that have been restructuring WE party systems for more than three decades by now. 


\section{References}

Bartels, Larry M. 2014. Pp. In Mass Politics in Tough Times, pp. 1-39 in Mass politics in tough times. Opinions, votes, and protest in the Great Recession, edited by Nancy Bermeo and Larry Bartels, Oxford U Press.

Bartolini, Stefano and Peter Mair 1990. Identity, competition, and electoral availability. The stabilisation of European electorates 1885-1985. Cambridge: Cambridge University Press.

Beissinger, Mark and Gwendolyn Sasse 2014. An End to Patience? The 2008 Global Financial Crisis and Political Protest in Eastern Europe, pp. 334-370 in Mass politics in tough times. Opinions, votes, and protest in the Great Recession, edited by Nancy Bermeo and Larry Bartels, Oxford U Press.

Casal Bertoa, Fernando 2014. Party systems and cleavage structures revisited: a sociological explanation of party system institutionalization in East Central Europe, Party Politics 20(1): 1636.

Clarke, Harold D. and Guy D. Whitten 2013. Hard choices in hard times: valence voting in Germany (2009), Electoral Studies 32: 445-451. 
Clarke, Harold D., D. Sanders, M.C. Stewart, Paul F. Whiteley 2009. Performance Politics and the British Voter. Cambridge: Cambridge University Press.

Coffey, Eva 2013. Pain tolerance. Economic voting in the Czech Republic, Electoral Studies 32: $432-437$.

Casal Bértoa, Fernando. Post-Communist Politics: On the Divergence (and/or Convergence) of East and West, Government and Opposition 48: 398-433

Duch, Raymond M. And Randolph T. Stevenson 2008. The Economic Vote. How Political and Economic Institutions Condition Election Results. Cambridge University Press.

Franklin, Mark N., Thomas T. Mackie and Henry Valen (eds.) 1992. Electoral change: responses to evolving social and attitudinal structures in Western countries. Cambridge: Cambridge U Press.

Gurr, Ted R. 1970. Why men rebel. Princeton: Princeton U Press.

Häusermann, Silja and Hanspeter Kriesi 2015. What do voters want? Dimensions and configurations in individual preferences and party choice, pp. 202-230 in Politics of advanced capitalism, edited by Pablo Beramendi, Silja Häusermann, Herbert Kitschelt and Hanspeter Kriesi, Cambridge: Cambridge U Press. 
Hellwig, Timothy 2012. Constructing accountability: party position taking and economic voting, Comparative Political Studies 45, 1: 91-118.

Hellwig, Timothy and David Samuels 2007. Voting in Open Economies. The Electoral Consequences of Globalization, Comparative Political Studies 40, 3: 283-306.

Kitschelt, Herbert and Philipp Rehm 2015. Party alignments: change and continuity, pp. 179-201 in Politics of advanced capitalism, edited by Pablo Beramendi, Silja Häusermann, Herbert Kitschelt and Hanspeter Kriesi, Cambridge: Cambridge U Press.

Klasnja, Marko and Joshua Tucker 2013. The Economy, Corruption, and the Vote: Evidence from experiments in Sweden and Moldova, Electoral Studies 32(3): 536-543.

Kriesi, Hanspeter 2014. The political consequences of the economic crisis in Europe: electoral punishment and popular protest, pp. 297-333 in Mass politics in tough times. Opinions, votes, and protest in the Great Recession, edited by Nancy Bermeo and Larry Bartels, Oxford U Press.

Kriesi, Hanspeter, Edgar Grande, Romain Lachat, Martin Dolezal, Simon Bornschier, Tim Frey 2006. 'Globalization and the transformation of the national political space: six European countries compared', European Journal of Political Research 45, 6: 921-957. 
Lewis-Beck, Michael S. and Mary Stegmaier 2007. Economic Models of Voting, pp. 519-537 in The Oxford Handbook of Political Behaviour, edited by Russell J. Dalton and Hans-Dieter Klingemann, Oxford U Press.

Lane, Jan-Erik and Svante O. Ersson 1996. European politics. An introduction. London: Sage.

Linde, Jonas 2012. Why feed the hand that bites you? Perceptions of procedural fairness and system support in post-communist democracies, European Journal of Political Research 5: 410434.

Lobo,Marina C.and Michael S. Lewis- Beck 2012. 'The Integration Hypothesis: How the European Union Shapes Economic Voting', Electoral Studies 31(3): 522-8.

Mainwaring, Scott 1999. Rethinking Party Systems in the Third Wave of Democratization: The Case of Brazil. Stanford University Press.

Mair, Peter 2013. Ruling the Void. The Hollowing of Western Democracy. London: Verso.

Marsh, Alan and Slava Mikhaylov 2012. Economic voting in a crisis: The Irish election of 2011, Electoral Studies 31: 478-84. 
Morgan, Jana 2013. Bankrupt representation and party system collapse. University Park: The Pennsylvania State University Press.

Neff Powell, Eleanor and Joshua A. Tucker 2013. Revisiting Electoral Volatility in PostCommunist Countries: New Data, New Results and New Approaches, British Journal of Political Science.

Pop-Eleches, Grigore (2010) 'Throwing out the Bums. Protest Voting and Unorthodox Parties after Communism’, World Politics 62, 2: 221-60

Powell, G. Bingham Jr. And Guy D. Whitten 1993. A Cross-National Analysis of Economic Voting: Taking Account of the Political Context, American Journal of Political Science 37, 2: $391-414$.

Roberts, Kenneth M. 2013. Market Reform, Programmatic (De)alignment, and Party System Stability in Latin America, Comparative Political Studies 46(11): 1422-1452.

Seawright, Jason 2012. Party System Collapse. The Roots of Crisis in Peru and Venezuela. Stanford U Press. 
Ucen, Peter 2007. Parties, Populism, and Anti-Establishment Politics in East Central Europe, SAIS Review, Vol 27, 1: 49-62. 
Table 1. Economic conditions and the performance of PM (Y $=\%$ votes $t+1-\%$ votes $t)$

\begin{tabular}{|c|c|c|c|c|c|c|c|c|c|c|}
\hline \multirow[b]{2}{*}{ Variables } & \multicolumn{5}{|c|}{ WE } & \multicolumn{5}{|c|}{ CEE } \\
\hline & M1 & $\mathrm{M} 2$ & M3 & M4 & M5 & M1 & $\mathrm{M} 2$ & M3 & M4 & M5 \\
\hline \multirow[t]{2}{*}{ Misery } & $-4.662 * * *$ & -1.642 & & & $-2.764 * *$ & -2.956 & -2.579 & & & -3.605 \\
\hline & $(-5.006)$ & $(-0.942)$ & & & $(-2.528)$ & $(-1.289)$ & $(-0.721)$ & & & $(-1.523)$ \\
\hline \multirow[t]{2}{*}{ Cross-country relative misery } & & & $-12.78 * * *$ & -3.911 & & & & -6.359 & -4.835 & \\
\hline & & & $(-4.488)$ & $(-0.942)$ & & & & $(-1.188)$ & $(-0.721)$ & \\
\hline \multicolumn{11}{|l|}{ Election timing. Ref (pre-crisis) } \\
\hline First post-crisis & $(-0.294)$ & $(-0.341)$ & $(-3.033)$ & $(1.503)$ & $(-0.845)$ & (0.159) & (0.159) & $(-0.521)$ & $(0.388)$ & $(0.554)$ \\
\hline \multirow[t]{2}{*}{ Second post-crisis } & -2.913 & -2.891 & $-7.238 * * *$ & 10.16 & -0.207 & -1.037 & -3.370 & -4.563 & -12.23 & 1.649 \\
\hline & $(-1.181)$ & $(-1.139)$ & $(-2.945)$ & $(1.321)$ & $(-0.0824)$ & $(-0.169)$ & $(-0.409)$ & $(-0.846)$ & $(-0.337)$ & $(0.249)$ \\
\hline \multirow[t]{2}{*}{ Coalition government } & -1.775 & -1.461 & -1.907 & -1.461 & -1.881 & 1.399 & 2.213 & 1.500 & 2.213 & 1.074 \\
\hline & $(-1.064)$ & $(-0.888)$ & $(-1.111)$ & $(-0.888)$ & $(-1.194)$ & $(0.206)$ & $(0.300)$ & $(0.220)$ & $(0.300)$ & (0.159) \\
\hline Swing & -0.110 & -0.138 & -1.799 & -3.288 & -0.133 & $-0.323 * *$ & $-0.363^{*}$ & $-0.319 * *$ & $-0.363^{*}$ & $-0.303 * *$ \\
\hline \multirow[t]{2}{*}{ Switzerland } & -2.296 & -3.288 & -0.102 & -0.138 & -2.333 & & & & & \\
\hline & $(-0.631)$ & $(-0.906)$ & $(-0.671)$ & $(-0.946)$ & $(-0.679)$ & & & & & \\
\hline \multirow[t]{2}{*}{ IMF intervention } & & & & & $-10.88 * * *$ & & & & & -5.517 \\
\hline & & & & & $(-2.920)$ & & & & & $(-1.067)$ \\
\hline \multicolumn{11}{|c|}{$\begin{array}{l}\text { Election timing * Misery | Cross-country } \\
\text { relative misery }\end{array}$} \\
\hline \multirow[t]{2}{*}{ First post-crisis } & & $-3.904 *$ & & $-14.74 * *$ & & & -1.481 & & -7.410 & \\
\hline & & $(-1.771)$ & & $(-2.409)$ & & & $(-0.316)$ & & $(-0.631)$ & \\
\hline \multirow[t]{2}{*}{ Second post-crisis } & & $-4.933^{*}$ & & $-18.19 * *$ & & & 3.348 & & 7.154 & \\
\hline & & $(-1.882)$ & & $(-2.339)$ & & & $(0.285)$ & & $(0.211)$ & \\
\hline \multirow[t]{2}{*}{ Constant } & -1.389 & -0.570 & $12.62 * * *$ & 3.776 & -0.800 & $-6.332 *$ & -5.582 & 2.239 & 1.243 & $-6.534^{*}$ \\
\hline & $(-1.187)$ & $(-0.467)$ & $(4.128)$ & $(0.883)$ & $(-0.713)$ & $(-1.818)$ & $(-1.338)$ & $(0.331)$ & 0.153 & $(-1.877)$ \\
\hline Observations & 69 & 69 & 69 & 69 & 69 & 37 & 37 & 37 & 37 & 37 \\
\hline R-squared & 0.401 & 0.442 & 0.365 & 0.445 & 0.475 & 0.171 & 0.177 & 0.16 & 0.18 & 0.201 \\
\hline
\end{tabular}

t-statistics in parentheses $* * * p<0.01, * * p<0.05, * p<0.1$ 
Figure 1: Misery and PM support in WE and CEE

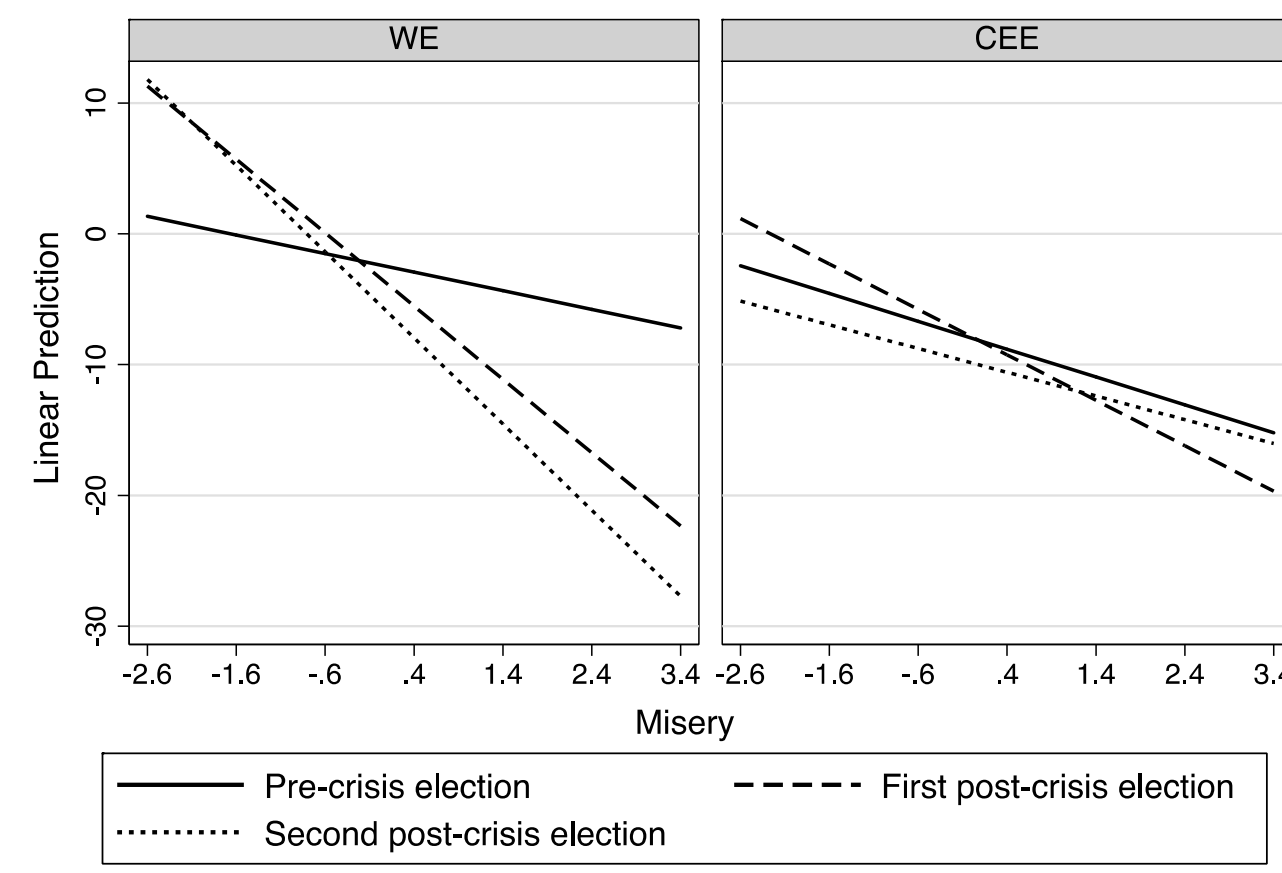

Note: Linear predictions based on model 1 table A.2 (Appendix A) 
Table 2: Political model: $\mathrm{PM} \mathrm{t}+1$ results as a function of time t votes and corruption

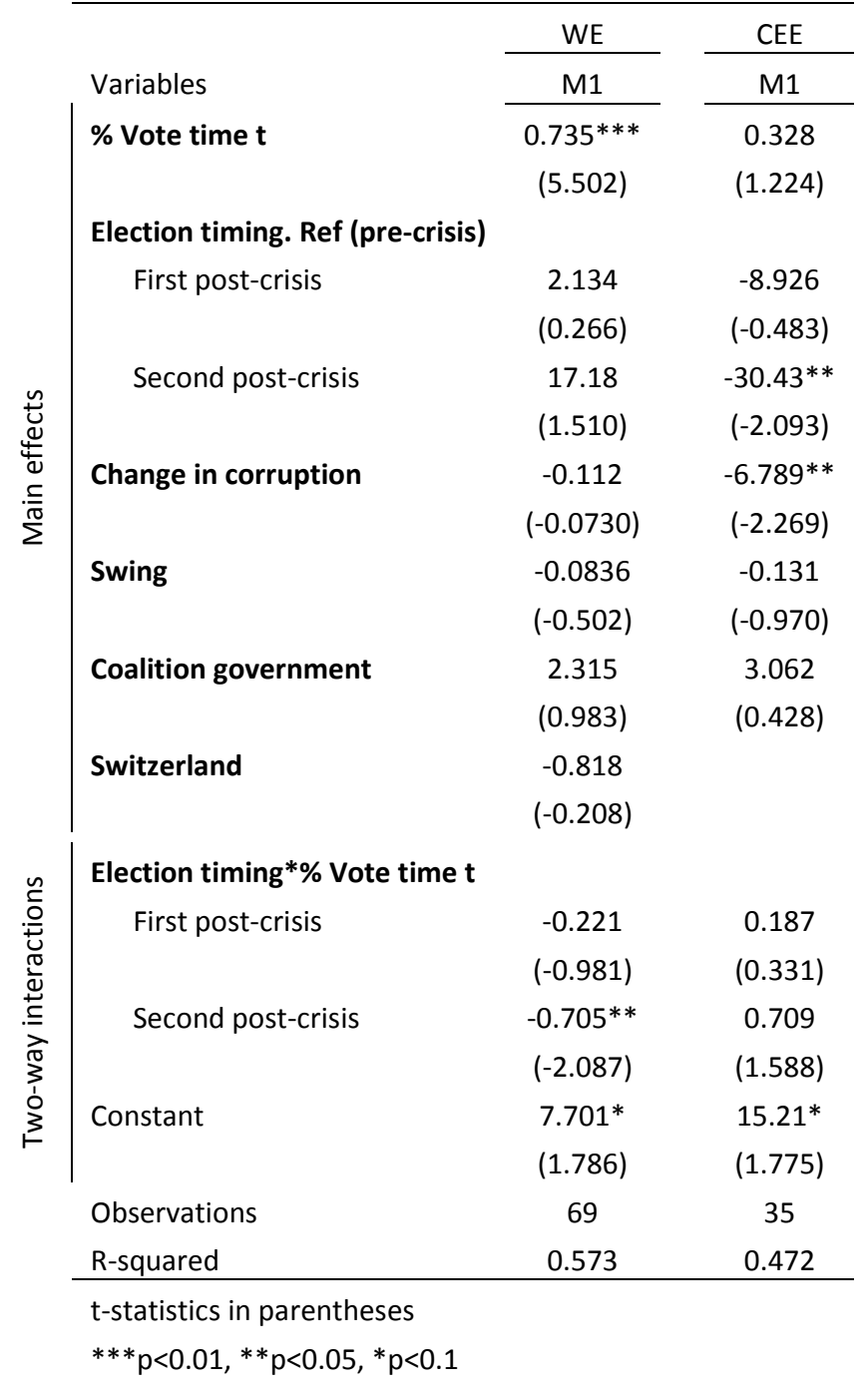


Figure 2: $\mathrm{PM}$ vote at time $\mathrm{t}$ as a predictor of vote at time $\mathrm{t}+1$
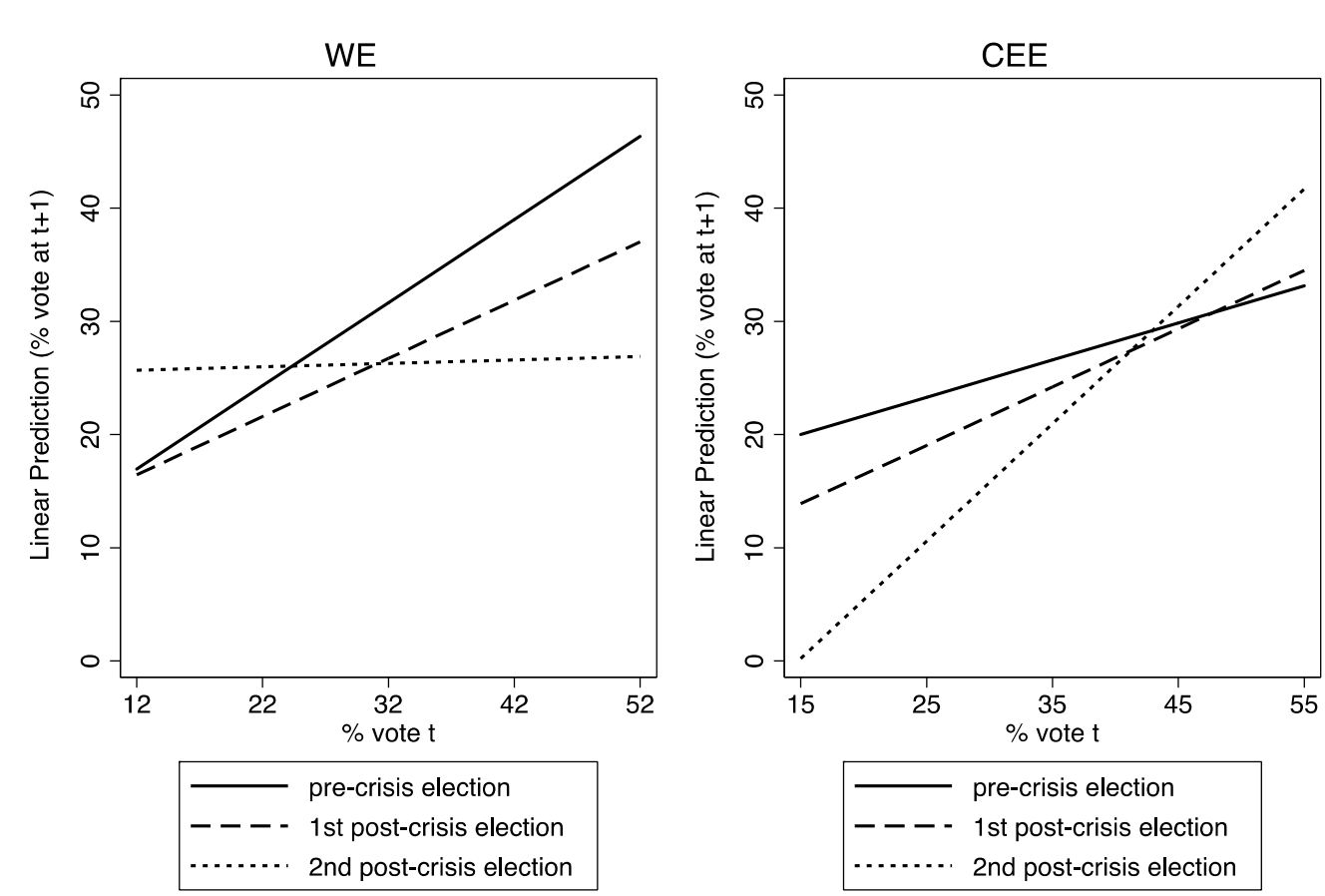

Note: Linear predictions based on M1 table 2

Table 3: Volatility in pre and post-crisis periods.

\begin{tabular}{|l|ccc|ccc|}
\hline \multirow{2}{*}{} & \multicolumn{3}{|c|}{ West } & \multicolumn{3}{c|}{ East } \\
\cline { 2 - 7 } & Pre-crisis & Post-crisis & Difference & Pre-crisis & Post-crisis & Difference \\
\hline Volatility (Total) & 9.3 & 14.9 & $5.6^{* * *}$ & 28.4 & 28.7 & 0.3 \\
Type-A & 0.9 & 3.4 & $2.6 * * *$ & 11.0 & 12.6 & 1.6 \\
Type-B & 8.5 & 11.5 & $3.0^{* *}$ & 17.4 & 14.8 & -2.6 \\
Explained variance (R2) in Volatility & 0.10 & 0.56 & $0.46^{\mathrm{NA}}$ & 0.35 & 0.51 & $0.16^{\mathrm{NA}}$ \\
(Total) by change in support of PM party & -0.3 & 0.7 & $1.0^{* * *}$ & -0.8 & 0.4 & $1.1^{* * *}$ \\
Misery & 2.3 & 2.8 & 0.5 & 5.5 & 5.2 & -0.3 \\
Corruption & & & & & & \\
\hline
\end{tabular}

${ }^{\star \star \star} p<0.01,{ }^{\star \star} p<0.05,{ }^{\star} p<0.1$, NA not applicable 
Figure 3: The determinants of volatility in WE and CEE

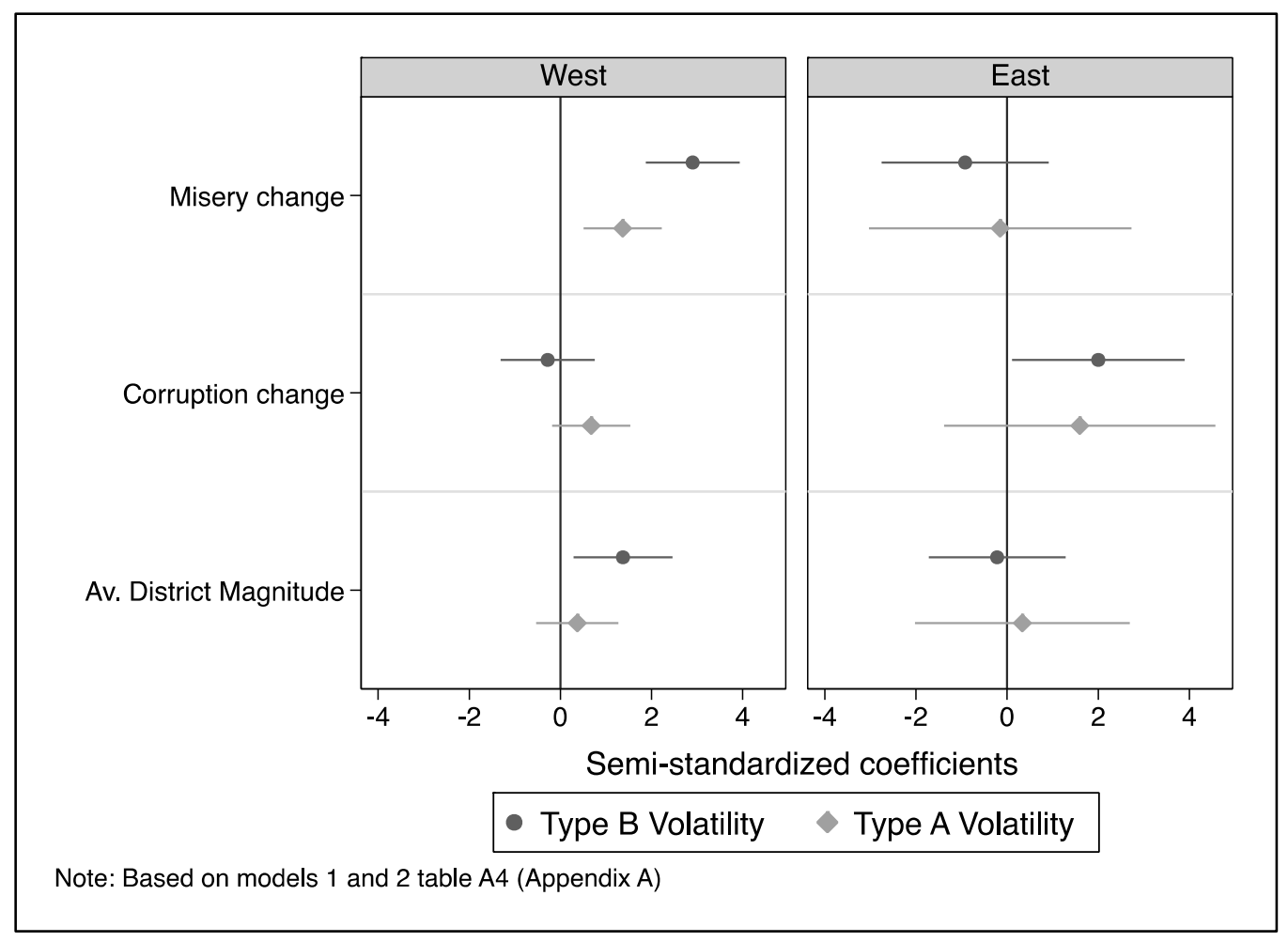


Table 4: The effects of misery, IMF intervention, and crisis for different parties ( $\mathrm{Y}=\%$ votes $\mathrm{t}+1$ - \% votes $\mathrm{t}$ )

\begin{tabular}{|c|c|c|c|c|}
\hline & M1-Baseline & M2-Misery & M3-IMF & M4-Misery and crisis \\
\hline \multirow[t]{2}{*}{ Prime Minister } & $-1.482 * *$ & $-1.438^{*}$ & $-1.405^{*}$ & $-1.287^{*}$ \\
\hline & $(-1.974)$ & $(-1.953)$ & $(-1.879)$ & $(-1.743)$ \\
\hline \multirow[t]{2}{*}{ Government } & $-3.619 * * *$ & $-3.504 * * *$ & $-3.657 * * *$ & $-3.633 * * *$ \\
\hline & $(-6.316)$ & $(-6.216)$ & $(-6.399)$ & $(-6.400)$ \\
\hline \multirow[t]{2}{*}{ Misery } & 0.226 & $-0.990 * *$ & 0.260 & 0.439 \\
\hline & $(0.732)$ & $(-2.459)$ & $(0.842)$ & $(0.580)$ \\
\hline \multirow[t]{2}{*}{ Crisis election } & -0.312 & -0.341 & -0.323 & -0.571 \\
\hline & $(-0.643)$ & $(-0.714)$ & $(-0.667)$ & $(-0.792)$ \\
\hline \multirow[t]{2}{*}{ IMF intervention } & -1.142 & -1.267 & $-4.216 * * *$ & -1.286 \\
\hline & $(-1.177)$ & $(-1.327)$ & $(-2.945)$ & $(-1.271)$ \\
\hline \multicolumn{5}{|l|}{ Party family: Ref. Mainstream } \\
\hline \multirow[t]{2}{*}{ Non-Mainstream } & $-1.608 * * *$ & $-1.721 * * *$ & $-1.923 * * *$ & $-2.323 * * *$ \\
\hline & $(-2.890)$ & $(-3.140)$ & $(-3.379)$ & $(-3.130)$ \\
\hline \multirow[t]{2}{*}{ Radical Left } & -0.627 & -0.755 & -0.884 & -1.348 \\
\hline & $(-0.831)$ & $(-1.015)$ & $(-1.140)$ & $(-1.265)$ \\
\hline \multirow[t]{2}{*}{ Populist radical right } & -0.425 & -0.688 & -0.777 & -1.436 \\
\hline & $(-0.515)$ & $(-0.825)$ & $(-0.922)$ & $(-1.249)$ \\
\hline \multirow[t]{2}{*}{ New parties } & $5.032 * * *$ & $4.243^{* * *}$ & $4.308 * * *$ & 2.736 \\
\hline & $(4.515)$ & $(3.685)$ & $(3.462)$ & $(1.110)$ \\
\hline \multicolumn{5}{|l|}{ Party family*Misery I IMF } \\
\hline \multirow[t]{2}{*}{ Non-Mainstream } & & $1.899 * * *$ & $4.734 * *$ & -0.188 \\
\hline & & $(3.587)$ & $(2.514)$ & $(-0.162)$ \\
\hline \multirow[t]{2}{*}{ Radical Left } & & $2.121 * * *$ & 3.897 & -0.385 \\
\hline & & $(2.811)$ & $(1.447)$ & $(-0.242)$ \\
\hline \multirow[t]{2}{*}{ Populist radical right } & & $2.358 * *$ & $6.291^{*}$ & -2.651 \\
\hline & & $(2.333)$ & $(1.775)$ & $(-0.822)$ \\
\hline \multirow[t]{2}{*}{ New parties } & & $2.969 * * *$ & $5.158^{*}$ & 4.064 \\
\hline & & (3.302) & $(1.923)$ & $(0.790)$ \\
\hline \multicolumn{5}{|l|}{ Party family*Crisis } \\
\hline \multirow[t]{2}{*}{ Non-Mainstream } & & & & 0.103 \\
\hline & & & & $(0.0937)$ \\
\hline \multirow[t]{2}{*}{ Radical Left } & & & & -0.315 \\
\hline & & & & $(-0.196)$ \\
\hline \multirow[t]{2}{*}{ Populist radical right } & & & & 0.133 \\
\hline & & & & $(0.0763)$ \\
\hline \multirow[t]{2}{*}{ New parties } & & & & 3.745 \\
\hline & & & & $(1.248)$ \\
\hline Crisis election*Misery & & & & $-1.921 * *$ \\
\hline & & & & $(-2.092)$ \\
\hline Party family*Misery*Crisis & & & & \\
\hline Non-Mainstream & & & & $2.886 * *$ \\
\hline & & & & $(2.104)$ \\
\hline Radical Left & & & & $3.673 *$ \\
\hline & & & & (1.938) \\
\hline Populist radical right & & & & $6.047^{*}$ \\
\hline & & & & $(1.757)$ \\
\hline New parties & & & & -1.774 \\
\hline & & & & $(-0.337)$ \\
\hline Constant & $1.906 * * *$ & $1.927 * * *$ & $2.103 * * *$ & $2.406 * * *$ \\
\hline & $(3.842)$ & (3.957) & $(4.221)$ & $(4.279)$ \\
\hline Observations & 480 & 480 & 480 & 480 \\
\hline R-squared & 0.197 & 0.234 & 0.212 & 0.254 \\
\hline
\end{tabular}


Figure 5: Misery and support of different parties in pre and post-crisis periods

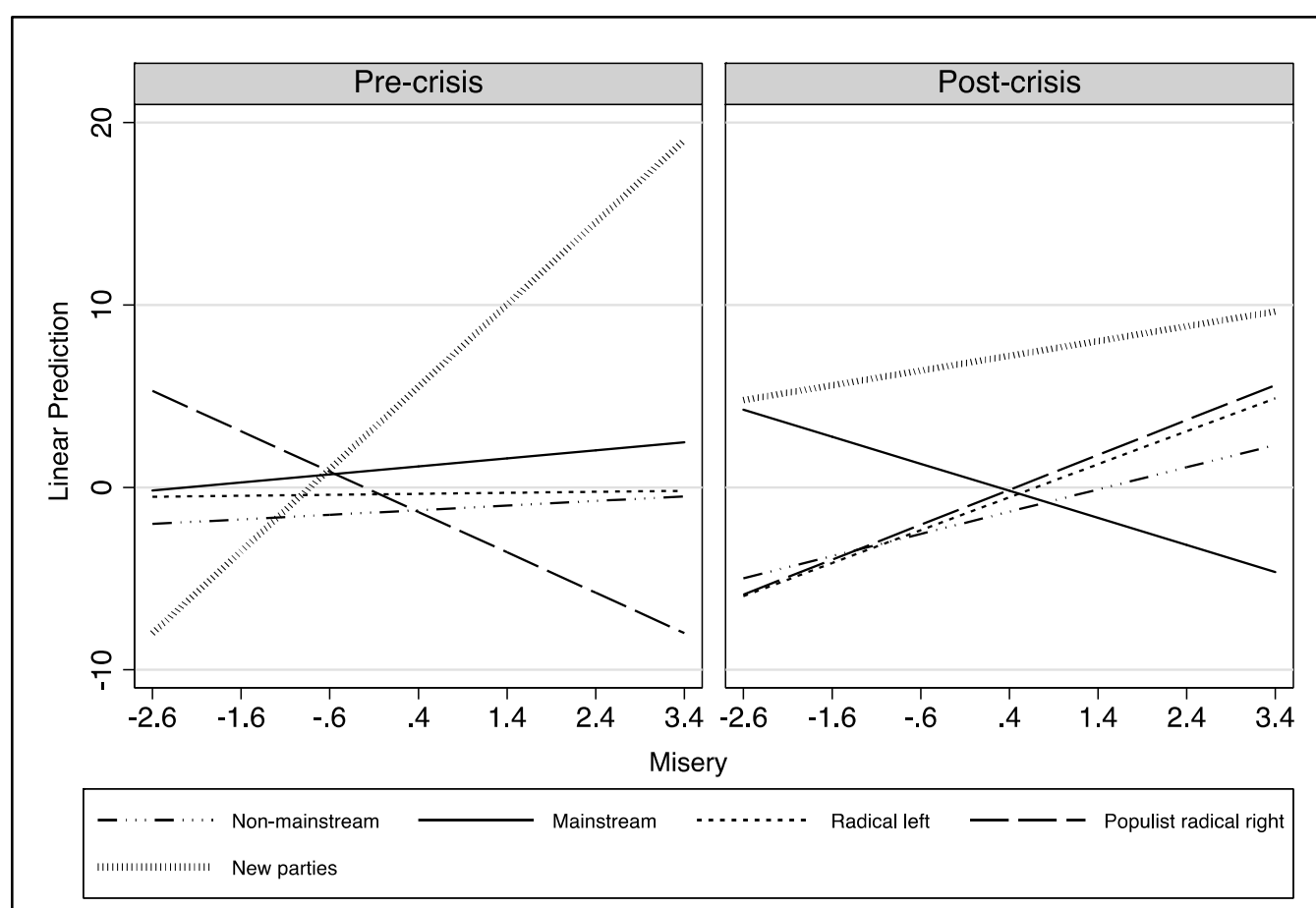

Note: Based on model 4 table 4 


\section{Appendix A: Additional tables}

Table A1: Factor analysis economic variables

\begin{tabular}{lc}
\hline & Loadings \\
\hline Unemployment rate change & 0.80 \\
GDP growth rate & -0.82 \\
Debt change & 0.87 \\
\hline \hline
\end{tabular}

Note: Entries are the result of a principal-component factor analysis. 1 component extracted, eigenvalue 2.06 .

Table A2: Pooled model. The impact of misery and timing of elections

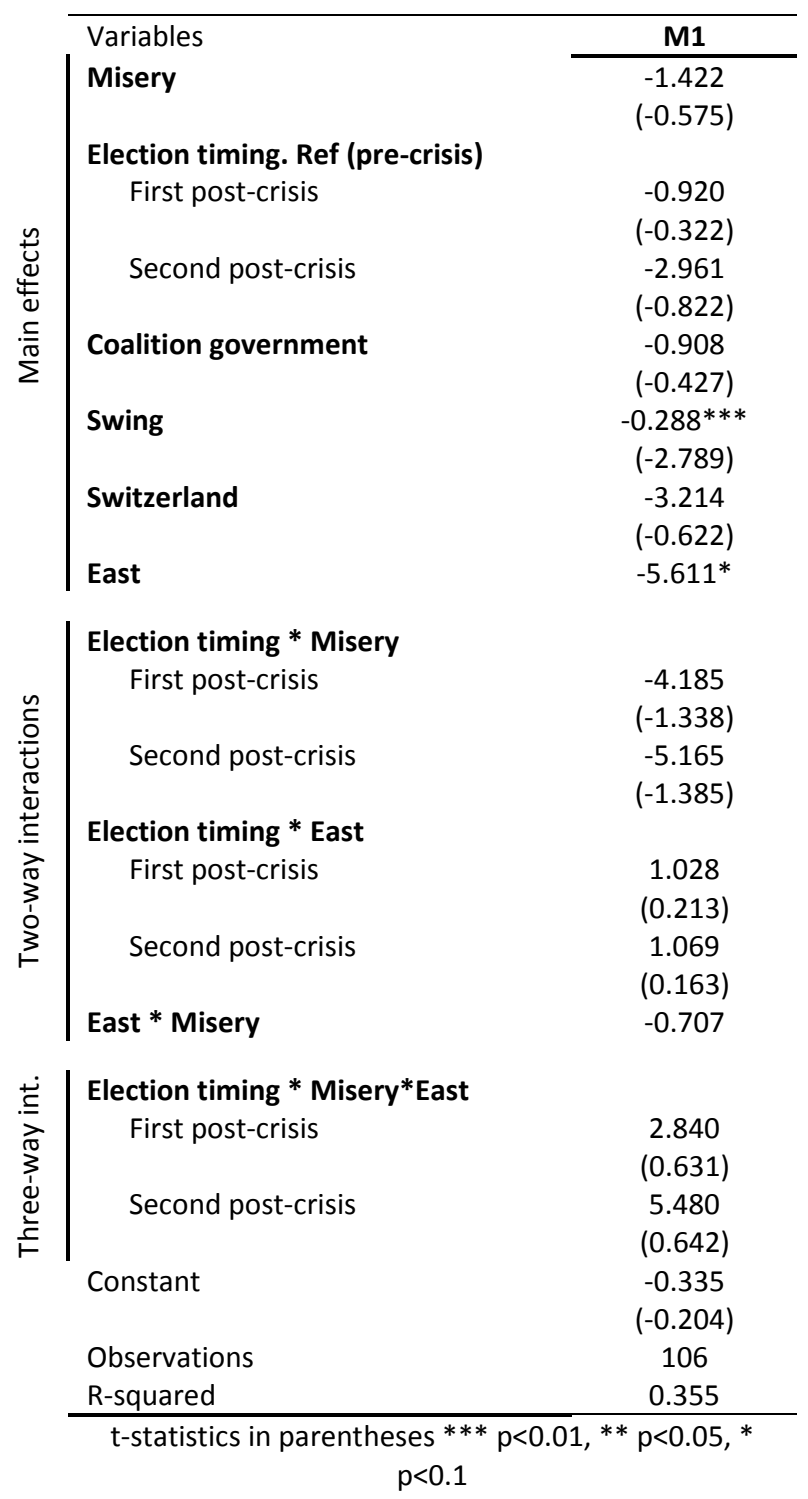


Table A3: Pooled model: Political model

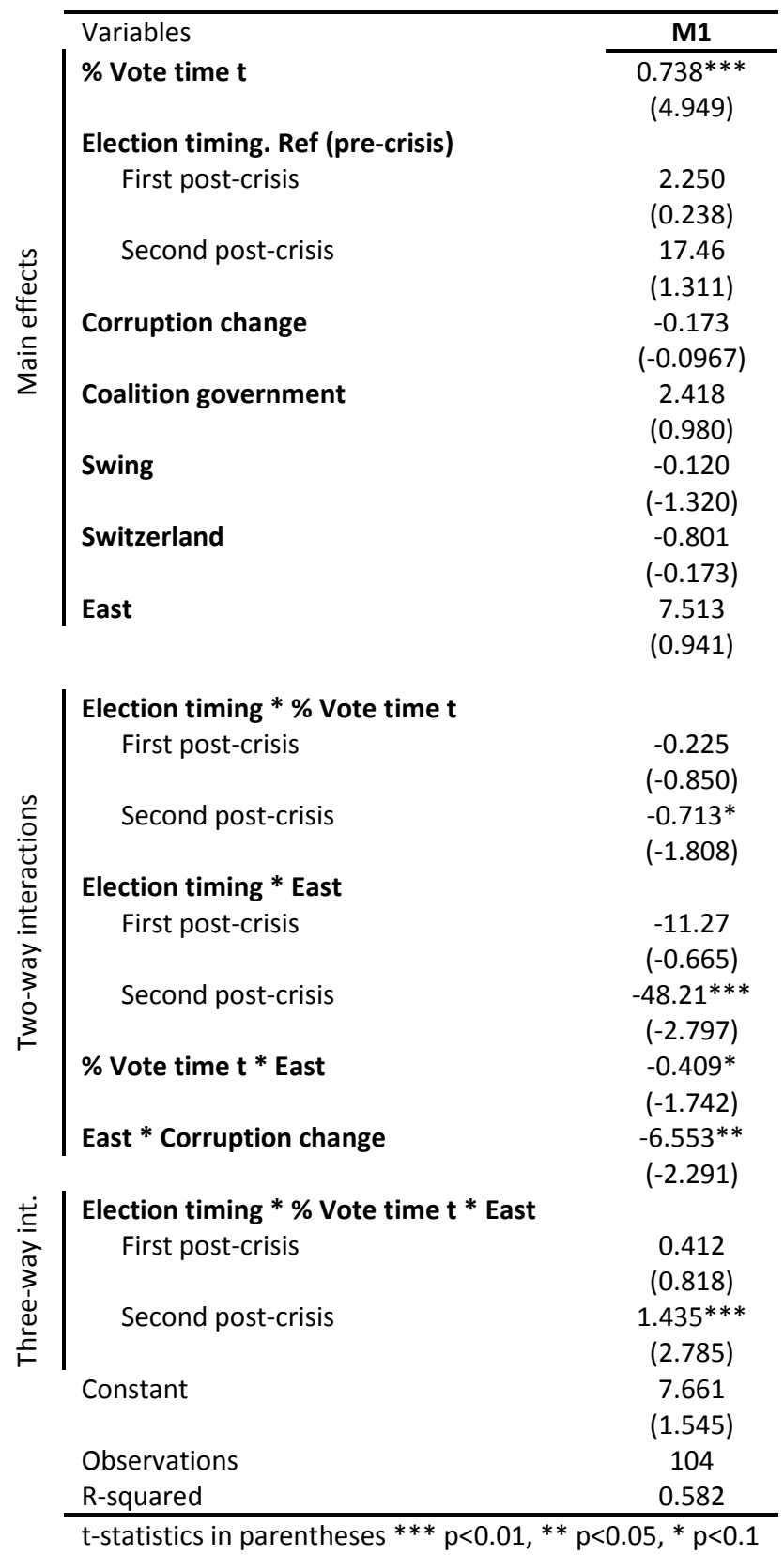


Table A4: Volatility, misery and corruption.

\begin{tabular}{|c|c|c|c|c|c|}
\hline & Type B WE & Type B CEE & Type A WE & Type A CEE & Total volatility \\
\hline Variables & M1 & M1 & M2 & M2 & M3 \\
\hline \multirow[t]{2}{*}{ Misery } & $2.906 * * *$ & $\begin{array}{l}-0.920 \\
\end{array}$ & $1.368 * * *$ & -0.150 & $4.297 * * *$ \\
\hline & $(4.703)$ & & & & \\
\hline \multirow[t]{2}{*}{ Corruption change } & -0.482 & $3.459 *$ & 1.166 & 2.754 & 0.691 \\
\hline & $(-0.452)$ & $(1.795)$ & $(1.312)$ & $(0.909)$ & $(0.360)$ \\
\hline \multirow[t]{2}{*}{ Av. District magnitude } & $0.0364 * *$ & -0.00578 & 0.00983 & 0.00890 & 0.0255 \\
\hline & $(2.110)$ & $(-0.247)$ & $(0.686)$ & $(0.242)$ & (1.141) \\
\hline East & & & & & $\begin{array}{c}16.37 * * * \\
(8.650)\end{array}$ \\
\hline \multirow[t]{2}{*}{ Misery * East } & & & & & $-5.375 * * *$ \\
\hline & & & & & $(-2.900)$ \\
\hline \multirow[t]{2}{*}{ Corruption * East } & & & & & $5.536^{*}$ \\
\hline & & & & & $(1.692)$ \\
\hline \multirow[t]{2}{*}{ Constant } & $8.795^{* * *}$ & $16.65^{* * *}$ & $1.426 * *$ & $10.84 * * *$ & $10.56 * * *$ \\
\hline & $(13.34)$ & $(13.11)$ & $(2.601)$ & (5.429) & (9.330) \\
\hline Observations & 70 & 34 & 70 & 34 & 104 \\
\hline R-squared & 0.294 & 0.100 & 0.123 & 0.031 & 0.488 \\
\hline
\end{tabular}

Table A5: Average marginal effects of misery on the change in votes between $t$ and $t+1$ for different party families in pre and post-crisis periods (From model 4 table 4)

\begin{tabular}{lcc}
\hline \multicolumn{1}{c}{ Party type } & Pre-crisis & Post-crisis \\
\hline Mainstream & 0.44 & $-1.48^{* * *}$ \\
& $(0.58)$ & $(-2.87)$ \\
Non-Mainstream & 0.25 & $1.22^{* *}$ \\
& $(0.29)$ & $(2.07)$ \\
Radical Left & 0.05 & $1.81^{*}$ \\
& $(0.04)$ & $(1.91)$ \\
Populist radical right & -2.21 & $1.92^{*}$ \\
& $(-0.71)$ & $(1.66)$ \\
New parties & 4.50 & 0.80 \\
& $(0.88)$ & $(0.79)$ \\
\hline t-statistics in parentheses & $* * * 0<0.01, * * \mathrm{p}<0.05, * \mathrm{p}<0.1$
\end{tabular}


Appendix B. Variables operationalization and summary statistics

\begin{tabular}{|c|c|c|c|c|c|}
\hline Variable & Operationalization & Mean / \% & SD & Min & Max \\
\hline \multicolumn{6}{|l|}{ Dependent Variables } \\
\hline Vote & $\begin{array}{l}\text { \% of votes for a given party at a given election. Sources: NSD European } \\
\text { Elections Database and Wolfram Nordsieck elections database }\end{array}$ & 12.52 & 11.92 & 0.00 & 58.63 \\
\hline Vote difference & $\begin{array}{l}\text { Difference in \% of votes for a given party between a given election and } \\
\text { the previous one. Sources: NSD European Elections Database and } \\
\text { Wolfram Nordsieck elections database }\end{array}$ & 0.00 & 7.12 & -35.99 & 42.74 \\
\hline Type A volatility & $\begin{array}{l}\text { Type A volatility is operationalized as follows: } \frac{\left|\sum_{o=1}^{n} p_{o t}+\sum_{w=1}^{n} p_{w(t+1)}\right|}{2} \text {, } \\
\text { where } \mathrm{o}=\mathrm{old} \text { disappearing parties that contested only the election at time } t \\
\text { and } \mathrm{w}=\text { new parties that contested only the election at time } \mathrm{t}+1 \text {, and } p \\
\text { represents the percentage of votes received by each of those parties, at } \\
\text { either } \mathrm{t} \text { or } \mathrm{t}+1 \text {. }\end{array}$ & 5.57 & 8.89 & 0.00 & 39.36 \\
\hline Type B volatility & $\begin{array}{l}\text { Type B volatility is operationalized as: } \frac{\sum_{i=1}^{n}\left|p_{i t}-p_{i(t+1)}\right|}{2} \text {, where } i= \\
\text { pre-existing parties. }\end{array}$ & 11.90 & 6.50 & 0.50 & 31.73 \\
\hline Total volatility & $\begin{array}{l}\text { The total volatility for a given election is calculated by adding up type A } \\
\text { and type B volatility, which is equivalent to the Pedersen index. }\end{array}$ & 17.48 & 12.68 & 0.5 & 50.11 \\
\hline \multicolumn{6}{|l|}{ Independent variables } \\
\hline GDP growth rate & $\begin{array}{l}\text { Change in GDP (in percent) between election at time } t+1 \text { and election at } \\
\text { time t. Source: Eurostat. Variable nama_gdp_c with "Gross Domestic } \\
\text { Product at market prices" unit selected }\end{array}$ & 23.98 & 24.49 & -41.90 & 128.88 \\
\hline Unemployment rate change & $\begin{array}{l}\text { Change in the unemployment rate (in percent) between election at time } \\
t+1 \text { and election at time t. Source: Eurostat. Variable Ifsq_urgan. }\end{array}$ & 0.37 & 3.82 & -9.90 & 13.40 \\
\hline Debt change & $\begin{array}{l}\text { Change in Government debt between election at time } t+1 \text { and election at } \\
\text { time t. Source: Eurostat. Variable General government gross debt with \% } \\
\text { of GDP option selected. }\end{array}$ & 4.24 & 16.33 & -42.30 & 79.50 \\
\hline Misery & $\begin{array}{l}\text { Variable predicted from principal components factor analysis of GDP } \\
\text { growth rate, Unemployment rate change, and Debt change (see appendix } \\
\text { A) }\end{array}$ & 0.00 & 1.00 & -2.66 & 3.56 \\
\hline Cross-country relative misery & $\begin{array}{l}\text { Variable measuring the degree to which the change in misery in a given } \\
\text { country deviates from the average change in WE and CEE in the pre or } \\
\text { post-crisis periods. Before computing the variable the misery indicator in } \\
\text { which this variable is based has been rescaled so that it only takes positive } \\
\text { values. For example the cross-country relative misery for the first German }\end{array}$ & 1 & 0.31 & 0 & 1.85 \\
\hline
\end{tabular}


$\frac{(\text { Misery Germany firs post-crisis election) })}{\text { (Misery WE post-crisis period })}$. Hence, higher values indicate a

relatively higher increase in misery

Variable that takes the value 1 if a given country is under an SBA or EFF agreement with the IMF and 0 otherwise. Source: IMF database

Change in corruption perception index between election at time $t$ and election at time $\mathrm{t}+1$. Source: Transparency International.

Corruption

Election timing (Categorical)

$$
\text { Pre-crisis }
$$

$t+1$ election took place before the Great-Recession

$t+1$ was the first election in a given country after the onset of the Great Recession

$t+1$ was the second election in a given country after the onset of the Great Recession

Variable that takes the value 1 if the election at time $t+1$ took place during the Great Recession and 0 otherwise

Average district magnitude of electoral districts in each country. Source: Quality of Government Dataset.

Variable that takes the value 1 if between the election at $t+1$ and $t$ the government of a country was formed by a coalition. Source: Wolfram Nordsieck elections database

Parties gains or losses in the previous elections. Votes at time $t$ - votes at time t-1. See Powell and Whitten 1993 p. 397

Variable that takes the value 1 for the Prime Minister's party between elections $t$ and $t+1$. (exception for Switzerland)

Variable that takes the value 1 for those parties that were part of the cabinet between election and time $t$ and $t+1$

See data and operationalization section and appendix $C$ for details. Only for WE

\section{Prime Minister}

\section{Government}

Party category (Categorical)

Non-mainstream

Mainstream

Radical left

Populist radical right 
APPENDIX C. Classification of parties in party categories (WE)

\begin{tabular}{|c|c|c|c|c|}
\hline Country & Party/ies & Name /s & Party category & Year founded \\
\hline \multirow{7}{*}{ Austria } & BZO & Bündnis Zukunft Österreich & Non-mainstream & 2005 \\
\hline & FPO & Freiheitliche Partei Österreichs & Populist radical right & 1956 \\
\hline & Greens & Die Grünen - Die Grüne Alternative & Non-mainstream & 1986 \\
\hline & SPÖ & Sozialdemokratische Partei Österreichs & Mainstream & 1888 \\
\hline & ÖVP & Österreichische Volkspartei & Mainstream & 1945 \\
\hline & FRANK & Team Frank Stronach & New & 2012 \\
\hline & NEOS & Das Neue Österreich und Liberales Forum & New & 2005 \\
\hline \multirow{6}{*}{ Belgium } & $\mathrm{CD} \& \mathrm{~V} / \mathrm{CDH}$ & Christian Democratic and Flemish / Humanist Democratic Centre & Mainstream & 1972 \\
\hline & ECOLO / GROEN & ECOLO / GROEN & Non-mainstream & 1981 \\
\hline & MR / VLD & Reform Movement / Open VLD & Mainstream & 1972 \\
\hline & PS / SPA & Socialist Party / Socialist Party Different & Mainstream & 1978 \\
\hline & PTB-PVDA & Worker's party of Belgium & Radical left & 1979 \\
\hline & $\mathrm{N}-\mathrm{VA} / \mathrm{VB} / \mathrm{LDD}$ & Flemish interest /New Flemish Alliance / Libertarian, Direct, Democratic & Populist radical right & $2001 / 2004 / 2007$ \\
\hline \multirow{7}{*}{ Cyprus } & EVROKO & European Party & Non-mainstream & 1996 \\
\hline & EDEK & Movement of Social Democrats & Mainstream & 1969 \\
\hline & AKEL & Progressive Party of Working People & Radical left & 1926 \\
\hline & DIKO & Democratic Party & Mainstream & 1976 \\
\hline & DISY & Democratic Rally & Mainstream & 1976 \\
\hline & EDI & United Democrats & Non-mainstream & 1993 \\
\hline & NEO & New Horizons & Non-mainstream & 2001 \\
\hline \multirow{9}{*}{ Denmark } & $\mathrm{KF}$ & Conservative People's Party & Mainstream & 1915 \\
\hline & DF & Danish People's Party & Populist radical right & 1995 \\
\hline & LA & Liberal Alliance & New / Non-mainstream & 2007 \\
\hline & V & Denmark's Liberal Party & Mainstream & 1910 \\
\hline & $\mathrm{EL}$ & Unity List - The Red-Greens & Radical left & 1989 \\
\hline & $\mathrm{RV}$ & Radical left & Mainstream & 1905 \\
\hline & $\mathrm{S}$ & Social Democracy & Mainstream & 1871 \\
\hline & SF & Socialist People's Party & Radical left & 1959 \\
\hline & $\mathrm{CIU}$ & Convergencia i Unió & Non-mainstream & 1978 \\
\hline
\end{tabular}




\begin{tabular}{|c|c|c|c|c|}
\hline \multirow{2}{*}{ Spain } & PP & Partido Popular & Mainstream & 1989 \\
\hline & IU & Izquierda Unida & Radical left & 1986 \\
\hline \multirow{5}{*}{ Finland } & KOK & National Coalition Party & Mainstream & 1918 \\
\hline & SFP & Swedish People's Party in Finland & Mainstream & 1906 \\
\hline & PS & True Finns & Populist radical right & 1995 \\
\hline & VAS & Left Alliance & Radical left & 1990 \\
\hline & SDP & Finnish Social Democratic Party & Mainstream & 1899 \\
\hline \multirow{3}{*}{ France } & UDF / MoDem & UDF / MoDem & Mainstream & 1978 \\
\hline & UMP / NC & Union for a Popular Movement / New Centre & Mainstream & 2002 \\
\hline & EELV / Verts & Europe Ecology The Green & Non-mainstream & 2010 \\
\hline \multirow{5}{*}{ Germany } & Grüne & Alliance 90 / The Greens & Non-mainstream & 1980 \\
\hline & $\mathrm{CDU} / \mathrm{CSU}$ & Christian Democratic Union of Germany & Mainstream & 1945 \\
\hline & FDP & Free Democratic Party & Mainstream & 1948 \\
\hline & PDS/ Linke & Die Linke & Radical left & 2007 \\
\hline & SPD & Social Democratic Party of Germany & Mainstream & 1875 \\
\hline \multirow{6}{*}{ Greece } & ANEL & Independent Greeks & New / Non-mainstream & 2012 \\
\hline & ND & New Democracy & Mainstream & 1974 \\
\hline & DIMAR & Democratic Left & New / Non-mainstream & 2010 \\
\hline & PASOK & Panhellenic Socialist Movement & Mainstream & 1981 \\
\hline & ChA & Golden Dawn & Populist radical right & 1993 \\
\hline & SYRIZA & Coalition of the Radical Left & Radical left & 2004 \\
\hline
\end{tabular}




\begin{tabular}{|c|c|c|c|c|}
\hline & LAOS & Popular Orthodox Rally & Populist radical right & 2000 \\
\hline \multirow{4}{*}{ Iceland } & SSF & Independence Party & Mainstream & 1929 \\
\hline & $\mathrm{XF}$ & Liberal Party & Non-mainstream & 2009 \\
\hline & $P$ & Pirate Party & New & 2012 \\
\hline & FSF & Progressive Party & Mainstream & 1916 \\
\hline \multirow{5}{*}{ Ireland } & FG & Family of the Irish & Mainstream & 1933 \\
\hline & GP & Green Party & Non-mainstream & 1981 \\
\hline & LAB & Labour Party & Mainstream & 1912 \\
\hline & PD & Progressive Democrats & Non-mainstream & 1985 \\
\hline & $\mathrm{SF}$ & We Ourselves & Radical left & 1905 \\
\hline \multirow{6}{*}{ Italy } & M5S & Five Star Movement & New & 2009 \\
\hline & PD & Democratic Party & Mainstream & 2007 \\
\hline & $\mathrm{PdL}$ & The People of Freedom & Mainstream & 2009 \\
\hline & SC & Civic Choice & New & 2012 \\
\hline & SEL & Left Ecology Freedom & New & 2010 \\
\hline & UDC & Unione di Centro & Non-mainstream & 2002 \\
\hline \multirow{5}{*}{ Luxembourg } & CSV & Christian Social People's Party & Mainstream & 1944 \\
\hline & GRËNG & The Greens & Non-mainstream & 1983 \\
\hline & DP & Democratic Party & Mainstream & 1955 \\
\hline & ADR & Alternative Democratic Reform Party & Non-mainstream & 1987 \\
\hline & LENK & The Left & New / Radical left & 1999 \\
\hline
\end{tabular}




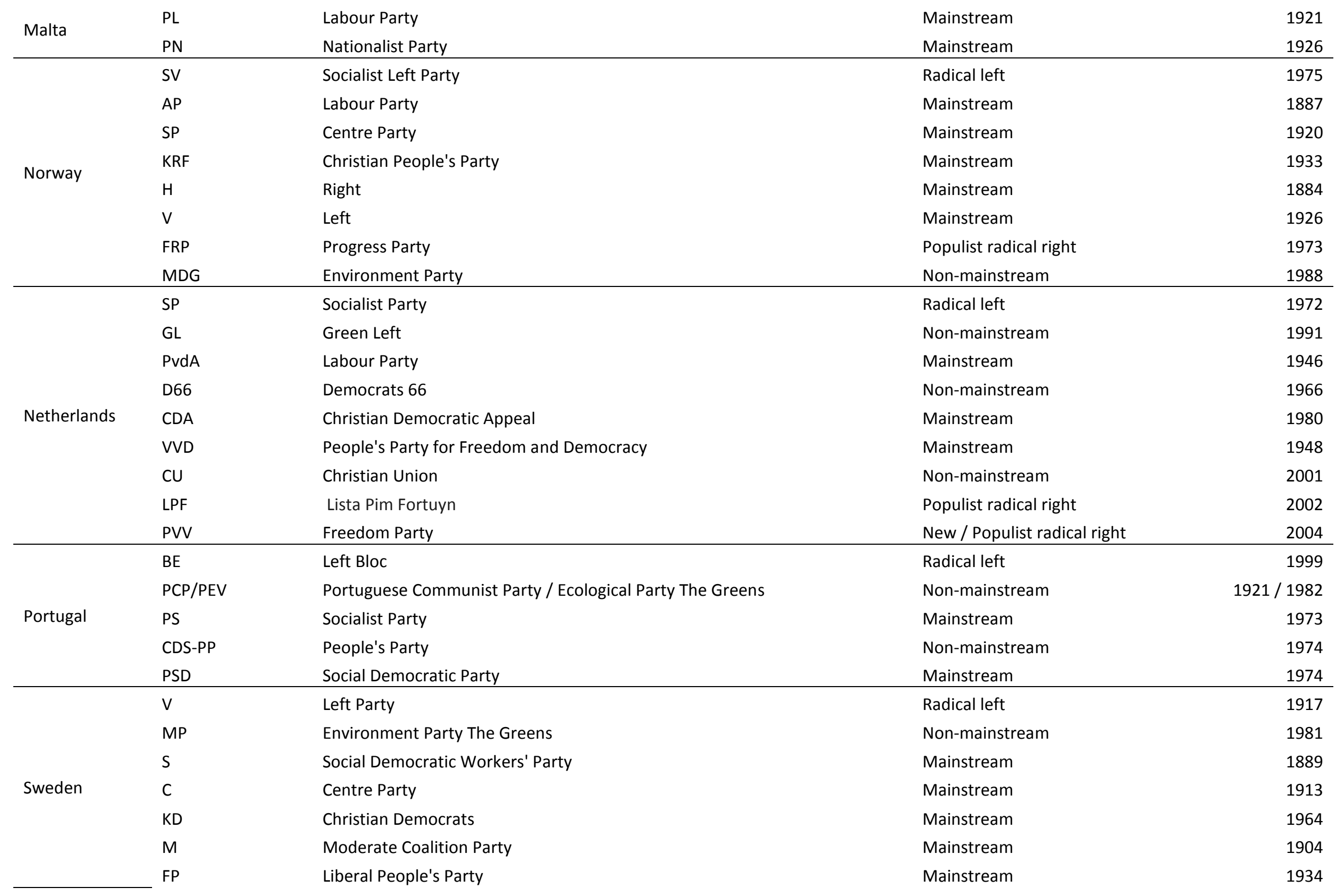




Switzerland

GPS

Green Party of Switzerland

Non-mainstream

1986

Social Democratic Party of Switzerland

Mainstream

1888

GLP

Green Liberal Party Switzerland

CVP + CSP Christian Democratic People's Party

New

2007

BDP

Civic Democratic Party Switzerland

Mainstream

1912

FDP The Liberals / Liberal Party of Switzerland

New

2008

SVP

Swiss People's Party

Mainstream

2009 / 1913

UK

CON

Labour

Populist radical right

1971

Mainstream

1906

LD

Conservative and Unionist Party

Mainstream

1832

Liberal Democrats

Non-mainstream

1988 